\title{
O QUE PODE A INTERVENÇÃO EDUCOMUNICATIVA AUDIOVISUAL? RELATOS DE UMA EXPERIÊNCIAÇÃO
}

\author{
WHAT CAN AUDIOVISUAL EDUCOMUNICATIVE INTERVENTION? REPORTS OF AN EXPERIENCE
}

¿QUÉ PUEDE LA INTERVENCIÓN EDUCOMUNICATIVA AUDIOVISUAL? RELATOS DE UNA EXPERIENCIA

MARQUES, Rodrigo Müller 1

MAZZARINO, Jane Márcia²

\section{RESUMO}

As Tecnologias de Informação e Comunicação (TICs) constroem cenários novos e complexos, que medeiam processos de ensino e de aprendizagem. A partir desse panorama e apoiando-se na educomunicação, realizou-se a produção de um audiovisual com alunos da rede pública de ensino da Escola Estadual de Ensino Médio Paverama/RS. No processo de construção do audiovisual participaram agricultores do município de Paverama e um professor. O objetivo é verificar proximidades e potencialidades possíveis entre a educomunicação e o ensino de história. A pesquisa tem viés metodológico e intervencionista, caracterizando-se como aplicada, bibliográfica, documental e de campo. Explora-se a pesquisa-ação e o olhar etnográfico através de diários de campo. A produção audiovisual demonstrou que é possível criar e compartilhar conhecimento através da educomunicação, que a criação de ecossistemas comunicativos abre um leque de possibilidades e que a experimentação audiovisual pode dinamizar aprendizagens.

Palavras-chave: Educação. Audiovisual. Comunicação.

\section{ABSTRACT}

Information and Communication Technologies (ICT) construct scenarios new and complex, which mediate teaching and learning processes. Starting of this panorama and based on educommunication, the production of a audiovisual system with students from the public school system of the State High School Paverama / RS. In the audiovisual construction process, farmers from the municipality of Paverama and a teacher. The objective is to check potentialities between educommunication and history teaching. The search has methodological and interventionist bias, characterizing itself as applied, bibliographic, documentary and field. It explores action research and the ethnographic through field journals. Audiovisual production has shown that it is possible to create and share knowledge through education, that ecosystem communication opens a range of possibilities and that audiovisual experimentation can stimulate learning.

Keywords: Education. Audiovisual. Communication. Educomunicacion.

\section{RESUMEN}

LasTecnologías de Información y Comunicación (TICs) construyenescenariosnuevos y complejos, que medíanprocesos de enseñanza y aprendizaje. A partir de ese panorama y apoyándoseenlaeducomunicación, se realizólaproducción de un audiovisual conalumnos de lared pública de enseñanza de laEscuela Estadual de Enseñanza Media Paverama / RS. Enelproceso de construccióndel audiovisual participaron agricultores delmunicipio de Paverama y unprofesor. El objetivo es verificar proximidades y potencialidades posibles entre laeducomunicación y laenseñanza de lahistoria. La investigacióntiene sesgo metodológico e intervencionista, caracterizándose como aplicada, bibliográfica, documental y de campo. Se explora lainvestigación-acción y la mirada etnográfica a través de diarios de campo. La producción audiovisual demostró que es posiblecrear y compartir conocimiento a través de la educomunicación, que lacreación de ecosistemas comunicativos abre um abanico de posibilidades y que la experimentación audiovisual puede dinamizar aprendizajes.

Palabras clave: Educación. Audiovisual. Comunicación.

\footnotetext{
1 Universidade do Vale do Taquari - Univates- Brasil

2 Universidade do Vale do Taquari - Univates- Brasil
} 


\section{INTRODUÇÃO}

As inovações tecnológicas fazem parte do nosso cotidiano. Além de comunicar, medeiam a maneira como nossas relações sociais são construídas. Quando perpassam o espaço escolar, geram demandas, até pouco, desconhecidas, e desafiam quem ensina e quem aprende, deslocando e ressignificando papéis.

O objetivo deste artigo é analisar a produção de um documentário de cunho histórico, construído a partir de um processo educomunicativo, a fim de verificar possíveis proximidades com o campo do ensino de história.

As primeiras práticas educomunicativas na América Latina datam de 1960, quando o cinema era uma das pautas. Na década de 1970 a televisão aparece como eixo central de discussão, ao passo que na década de 1980 surge a busca por uma comunicação que se volte para a resistência cultural e a luta pela democracia, emergindo um novo sentido de fazer educação para a comunicação (fenômeno marcadamente político e humano), além de ser vista como possibilidade de intervenção e mudança da realidade (SOARES, 2014).

Ainda na década de 1980, ocorreram encontros organizados pela UNESCO (Organização das Nações Unidas para a Educação, Ciência e Cultura) na América do Sul, que dão forma à educomunicação. A década de 1990 é perpassada pela influência dos Estudos Culturais, quando há uma superação da bipolaridade (emissor $\mathrm{x}$ receptor), que fora influenciada pelo paradigma funcionalista (fundado no tecnicismo e centrado nos meios). As práticas da comunicação passam então a ser entendidas como fluxos culturais, que englobam crenças, costumes, sonhos e medos definidos no cotidiano (SOARES, 2014).

O termo "educomunicação" ainda está em construção, sendo assim, "[...] não tem condições de ser descrito por definições sumárias e definitivas" (SOARES, 2014, p.16). Embora possamos tratá-lo como campo que trabalha com a esfera educacional (na sua perspectiva filosófica e pedagógica) e da comunicação.

No modelo atual de comunicação, cada vez mais interativo, dinâmico, veloz e participativo (MUSSO, 2006), a educomunicação possibilita a problematização e a reflexão sobre modelos comunicacionais e educativos. Tessara descreve a educomunicação como:

\footnotetext{
Processo de comunicação com intencionalidade educacional expressa e que envolve a democratização da produção e de gestão da informação nos meios de comunicação em diversos formatos, ou na comunicação presencial. Educomunicação pode ser definida também, nas práticas educativas que visam levar à apropriação democrática e autônoma de produtos de comunicação, por meio dos quais os participantes passam a exercer seu direito de produzir informação e comunicação (TESSARA apud BRASIL, 2005).
}

O termo remete a diversas dimensões, vinculadas a suas aplicabilidades, entre elas, o contato com o socioambientalismo, não se restringindo a essa seara, já que pode ter utilizações em vários 
campos. A educomunicação caracteriza-se pelo relacionamento dialógico e participativo, diz respeito a uma mudança de atitudes e de concepções, além de ser um campo de intervenção social que faz uso das tecnologias (APARICI, 2014).

O Programa Nacional de Educomunicação Sociombiental (BRASIL, 2005) demonstra que a educomunicação tem grande importância para a área da educação ambiental e especifica as dimensões, subáreas e princípios que norteiam o campo. Como dimensões consta que a) refere-se a um espaço de construção epistemológica; b) refere-se à educação para recepção crítica de conteúdos da comunicação de massa; c) busca promover "ecossistemas comunicativos", com articulações entre o virtual e o presencial, num esquema de teia educativa, baseada em encontros, comunidades interpretativas, fortalecimento de elos e com caracterização de informação e formação; d) corresponde à gestão participativa dos meios e defesa do direito à comunicação; e) diz respeito aos processos para formação de habilidades comunicativas; f) refere-se à compreensão do potencial educativo da comunicação social.

Como área de intervenção constam: a) expressão comunicativa, através do uso dos recursos da informação e das artes; b) educação para a comunicação, configurada nos esforços sistemáticos de educadores, buscando colaborar com os usuários dos meios massivos na formação do indivíduo, frente às mensagens editadas e veiculadas por sistemas de comunicação; c) mediação tecnológica nos espaços educativos, que constitui-se de esforços no sentido de identificar a natureza da interatividade propiciada pelas novas tecnologias e seus instrumentos na oportunidade de democratização do uso e do acesso às mesmas, desmitificando-as e colocando-as a serviço da sociedade; d) pedagogia da comunicação no contexto escolar, prevendo a multiplicação de ação dos agentes educativos (aluno e professor trabalhando juntos); e) gestão da comunicação nos espaços educativos, que se caracteriza pela abordagem sistêmica das relações entre as atividades humanas e os recursos de comunicação, garantindo um planejamento e uma implementação organizada das ações educomunicativas; f) reflexão epistemológica, a qual inclui a pesquisa e a avaliação sistemática, na tentativa de compreender as complexidades envoltas nas relações entre comunicação e educação (BRASIL, 2005; SOARES, 2011).

Além das dimensões e áreas, há 8 princípios básicos da educomunicação (BRASIL, 2005): a) compromisso com o diálogo permanente e continuado, que deve promover inclusão de atores e valorizar experiências, modos de ver e fazer; b) compromisso com a interatividade e produção participativa de conteúdos; c) transversalidade e valorização das interfaces com todos os campos do saber; d) encontro/diálogos de saberes, promovendo o contato/troca entre diferentes pessoas, instituições, gêneros, culturas, territórios, etc.; e) compromisso com a proteção e valorização do conhecimento tradicional e popular; f) vinculação direta com a democratização da comunicação e com a acessibilidade à informação, buscando dar condições de acesso iguais à informação e aos meios de produção; g) compromisso com o direito à comunicação e com a ação emancipatória dos cidadãos. h) preocupação com a não discriminação e o respeito à individualidade e diversidade humana. Os princípios educomunicativos constituíram-se nas categorias de análise da prática de produção audiovisual no contexto escolar relatado neste artigo. 
A experiência se deu atrelada à disciplina de História. Considera-se que a escola é um espaço físico coordenado e significado por gestores, educadores e alunos, com dinâmicas próprias. Dadas as características do campo da Educomunicação, entende-se que ele pode auxiliar muito no que tange ao ensino, especialmente quando refere-se à pesquisa em História.

\section{MÉTODO}

O uso de educomunicação no espaço escolar e fora dele aparece como uma proposta repleta de possibilidades. Para explorar os campos, analisar algumas variáveis, contextualizar o tempo/espaço do presente estudo e apresentar apontamentos e propostas de uso(s) da educomunicação no ensino de história, optou-se por uma pesquisa de viés metodológico, intervencionista e aplicada. Quanto aos meios define-se como bibliográfica, documental e de campo. Explora-se a pesquisa ação e o olhar etnográfico (AGROSINO, 2009; GASKELL, 2002; GIL, 2010; VERGARA, 2005).

A pesquisa ação, enquanto metodologia de intervenção, busca superar desafios através da interação colaborativa e participativa entre pesquisador e grupo. Ao se colocar no campo, em ação, e fazer o uso dos diários de campo para formular relatos de "tom etnográfico" (descrição e análise dos acontecimentos observados), o pesquisador é capaz de experimentar junto com o grupo diversas experiências (AGROSINO, 2009; GIL, 2010). Assim, a pesquisa ação abre espaço para a experiência, gerando a experienciação, que envolve pesquisador, grupo e campo em uma experiência que afeta a todos e tem uma ação como objetivo, além do próprio processo de produção de dados para a pesquisa.

Segundo Larrosa (2002), a experiência é o que "nos passa", o que nos toca, o que nos acontece. A ação se coloca como possibilidade de experiência, quando o sujeito participa, se expõe. Ela se dá no encontro, na relação com algo que se prova, se experimenta. O sujeito da experiência “ [...] tem algo desse ser fascinante que se expõe atravessando um espaço indeterminado e perigoso, pondo-se nele à prova e buscando nele sua oportunidade, sua ocasião [...]" (LARROSA, 2002, p. 25).

A experiência se coloca como vivência que significa, através da exposição e da abertura à transformação, como um tipo de paixão que atravessa o sujeito no seu experienciar. Ela não se esvazia no momento. Perdura, significa, ecoa. O saber da experiência acontece na relação de mediação entre o conhecimento e a vida humana, portanto ocorre no modo como alguém vai respondendo ao que the vai acontecendo (LARROSA, 2002).

A experienciação relatada neste artigo levou em conta os princípios da educomunicação: dialogicidade, interatividade, valorização e diálogo entre saberes, democracia, direito a comunicar-se e respeito à diversidade. A experienciação ocorreu a partir dos atravessamentos sentidos pelos sujeitos da ação, daqueles que compuseram o audiovisual. Estudantes e pesquisadores que experienciaram, expuseram-se e se deixaram tocar pelo objetivo e pelo subjetivo, envolvendo-se nas ações da pesquisa. Estar, presenciar, construir e sentir foram elementos entrelaçados e dinamizados a partir dos princípios educomunicativos, que deram forma, conteúdo e emoção ao audiovisual, à história, aos sujeitos envolvidos e à própria experienciação. 
O contexto é o município de Paverama, interior do Rio Grande do Sul. Um grupo de alunos foi convidado para participar da produção de um audiovisual, como proposta de pesquisa do Trabalho de Conclusão do curso de História. A pesquisa de campo caracterizou-se como participante, na medida em que o "pesquisado" tomou decisões sobre o processo (GIL, 2010). Os alunos estiveram envolvidos na produção audiovisual em suas diferentes etapas: roteiro, gravações e edição.

Optou-se por produzir um audiovisual em que valorizam-se os saberes que transitam na comunidade, aproximando os alunos dela, a partir da criação de um produto para uso didático que fosse decorrente de um processo de pesquisa. Assim, o aluno se tornaria pesquisador e produtor de conhecimento histórico.

Participaram da intervenção audiovisual, 3 meninas e 5 meninos, que livremente aderiram à proposta, já que tinham a demanda de apresentar um trabalho na Feira do Conhecimento da Escola Estadual de Ensino Médio Paverama, que aconteceria no final de outubro de 2016. A Feira é um evento no qual são expostas pesquisas realizadas por alunos.

Realizaram-se encontros sistemáticos com o grupo, todas as quartas-feiras, durante três meses. Além disso, organizaram-se saídas à campo aos sábados e/ou domingos para captação de imagens, totalizando 10 encontros na escola, quatro saídas a campo e duas idas à Feira do Conhecimento.

Durante a produção do documentário utilizamos o diário de campo, com o intuito de mapear as dinâmicas do grupo, coletando dados para posterior análise. O diário baseou-se no método etnográfico, que caracteriza-se por ser multifatorial (coleta qualitativa e quantitativa). Realizou-se a observação do grupo, que estava ciente do processo e procedeu-se a coleta de dados sistemática e análise do diário. $O$ registro escrito é de suma importância. $O$ ato de tomar nota nos diários permite exercitar a habilidade de "revisitar a experiência" (AGROSINO, 2009; ECKERT; ROCHA, 2008).

\section{O PROCESSO}

As análises do processo de produção audiovisual estão divididas em cinco etapas: escolha do tema; decisões de abordagem e processo de construção; edição; produto; mostra.

a) Escolha do tema

O tema inicialmente proposto pelo grupo era a Revolução Industrial. Após alguma conversa, optou-se por manter o tema inicial, porém trazendo-o para um contexto mais próximo, ao relacioná-lo com a entrada das máquinas no mundo rural e os desdobramentos de processos modernizantes pelos quais o Brasil, e seus espaços rurais, passaram nas últimas décadas. O município de Paverama foi a delimitação territorial. O tema e o título do trabalho definiram-se já no primeiro encontro, justificando o argumento principal do audiovisual: "Agricultura: do manual ao automático".

A escolha do título se deu de forma colaborativa, pois no final do encontro, o aluno $\mathrm{A}^{3}$ sugeriu o título: "Da mão-de-obra ao automático". O grupo gostou da ideia, mas no decorrer da conversa

\footnotetext{
${ }^{3}$ Optou-se por usar letras para diferenciação de falas dos alunos participantes.
} 
escolheu-se de forma deliberativa a sugestão do aluno B: "Agricultura: do manual ao automático" (DIÁRIO DE CAMPO, 03/08/2016).

A delimitação temporal foi fixada da primeira metade do século XX até o tempo "presente", utilizando o conceito de história de média/longa duração (BRAUDEL,1992). Para o autor, a história deve observar as mudanças estruturais que acontecem na longa duração. O tempo curto estaria relacionado aos eventos. Braudel fala dos eventos como algo explosivo, mas que não dura, enquanto as estruturas mudam, porém, levam longos períodos para que essas mudanças ocorram. $O$ fator tempo aqui não chega a ser insignificante, mas não se restringiu as suas delimitações, dialogando entre a média duração (tempo das conjunturas) e a longa duração (o tempo é quase insignificante). É uma linha tênue, na qual equilibrou-se durante essa pesquisa. A escolha pela história de média/longa duração justifica-se por se tratar de uma pesquisa que leva em conta a história do e no espaço rural, suas estruturas, processos de mudança no território e nas relações sociais, alteradas a partir do advento de máquinas.

A proposta por explorar essa temática gerou engajamento do grupo, já que alguns membros relataram que os pais ou avós trabalharam e/ou ainda trabalham na agricultura, como explicita o aluno B: "[...] sei como é o trabalho na roça, mas é interessante gravar e mostrar. Muita gente não conhece [...]" (DIÁRIO DE CAMPO, 03/08/2016).

A partir da escolha do tema se deu início ao processo de roteirização, tomando-se decisões sobre o modo de abordagem e o processo de construção. $O$ roteiro foi feito em conjunto e cada membro do grupo participou em diferentes momentos, dando ideias, construindo objetivos, sugerindo perguntas, etc.

Durante o processo, notei a participação e a fala de todos do grupo, lançando opiniões e ideias. Sugeriram também o que buscar nas entrevistas, onde entrevistar, etc. A partir daí pode-se iniciar a roteirização (DIÁRIO DE CAMPO, 17/08/2016).

Por ser um documentário, algo que busca uma aproximação com a realidade, o roteiro deixava aberturas para possiveis inserções de dados, fotos, filmagens, lugares, entrevistas, etc. A tarefa de fazer um roteiro pode ser visto como um processo permanentemente em construção, que segue várias etapas e "[...] exige planejamento e conhecimento prévio da história a ser contada: seu começo, meio e final." (SEPAC, 2007, p.57).

Para construção do roteiro partiu-se das ideias dadas pelos alunos, suas sugestões e apontamentos e, a partir daí os pesquisadores relacionavam todas as inferências, enviando, posteriormente, aos alunos, o esquema proposto, como pode-se ver no quadro 1.

\section{Quadro 1 - Roteiro.}




\begin{tabular}{|c|c|c|c|c|}
\hline O que abordar & $\begin{array}{l}\text { Objetivo do que } \\
\text { se está mostrando }\end{array}$ & Como mostrar & Cena & $\begin{array}{l}\text { Observações } \\
\text { (recursos técnicos } \\
\text { necessários, } \\
\text { espaços de } \\
\text { filmagem, etc.) }\end{array}$ \\
\hline $\begin{array}{l}\text { Diferenças entre as } \\
\text { décadas passadas } \\
\text { e os tempos atuais; } \\
\text { Mostrar as tradições } \\
\text { que ainda } \\
\text { perduram; } \\
\text { Abordar o dia-a-dia } \\
\text { do agricultor. }\end{array}$ & $\begin{array}{l}\text { Mostrar a } \\
\text { importância do } \\
\text { agricultor; } \\
\text { llustrar a } \\
\text { importância das } \\
\text { mudanças históricas } \\
\text { no presente; } \\
\text { Elencar prós e } \\
\text { contras das } \\
\text { mudanças nos } \\
\text { modos de produção } \\
\text { agrícola; } \\
\text { Contar um pouco da } \\
\text { história do } \\
\text { município; } \\
\text { Ouvir e mostrar } \\
\text { traços da história } \\
\text { das pessoas que } \\
\text { formam e formaram } \\
\text { o município de } \\
\text { Paverama. }\end{array}$ & $\begin{array}{l}\text { Através de } \\
\text { paisagens; } \\
\text { Falas dos } \\
\text { agricultores; } \\
\text { Fotografias } \\
\text { "antigas". }\end{array}$ & $\begin{array}{l}\text { Ao chegar no local } \\
\text { buscar-se-á um } \\
\text { ambiente com boa } \\
\text { iluminação e } \\
\text { propício para as } \\
\text { entrevistas. Optou- } \\
\text { se por deixar as } \\
\text { cenas em aberto. }\end{array}$ & $\begin{array}{l}\text { Os espaços de } \\
\text { filmagens serão as } \\
\text { localidades do } \\
\text { interior do município } \\
\text { (em casas, galpões, } \\
\text { ou ao ar livre); } \\
\text { Os recursos serão a } \\
\text { câmera, o microfone } \\
\text { de lapela e o } \\
\text { veículo para } \\
\text { locomoção até as } \\
\text { localidades. }\end{array}$ \\
\hline
\end{tabular}

Fonte: Dos autores.

Optou-se por um tom mais livre, elencando-se pontos a serem abordados para a construção audiovisual e da história que queríamos contar/explorar, tendo em vista que os participantes não possuíam conhecimentos aprofundados sobre roteirização. Definiu-se que o foco seria a realidade da agricultura no presente em sua relação com o passado. Esta decisão tomaria forma levando-se em conta algumas estratégias: a) sair cedo nos dias de gravação (por volta das 6:00 - 7:00 horas) para filmar alguns agricultores no seu período inicial de trabalho; b) conversar sobre o modo tradicional de realizar suas tarefas; c) entrevistá-los em roupas utilizadas em seu trabalho diário; d) deixar que o agricultor entrevistado falasse e se expressasse de seu modo, sem falas prontas ou ensaiadas, buscando maior naturalidade.

Após o roteiro ser finalizado, iniciou-se o processo de gravações das entrevistas, que ocorreram em quatro saídas a campo (aos finais de semana). Nas quartas-feiras o grupo se reunia na escola para avaliar as entrevistas e o processo. 
Todos os alunos participaram em algum momento das gravações, que incluíram entrevistas com agricultores de diferentes localidades de Paverama. Foram entrevistados agricultores que mostraram disponibilidade.

Notei que hoje mais alunos usaram a câmera e não necessariamente fui eu quem induzi [...] filmaram e fotografaram tanto a paisagem quanto a entrevista, assinalando certa maturidade ao ter cuidado com enquadramento e a qualidade quando da entrevista e liberdade para brincar de fotografar (DIÁRIO DE CAMPO, 17/09/2016).

As práticas de saídas a campo e a realização das entrevistas mostraram-se um modo de aprender e produzir conhecimento com e para o aluno, além de torná-lo parte importante do processo, ao ser ele quem questionava, mesmo quando sentia certo estranhamento. $A$ fala da aluna $C$ explicita diferentes modos de participação: "Eu gosto de filmar, mas na hora de perguntar eu fico sem saber o que falar." (DIÁRIO DE CAMPO, 17/09/2016). Este tipo de posicionamento foi recorrente.

Durante a reunião, os alunos usaram muitas vezes a colocação "tu viu quando eu perguntei o que ele disse [...]" e "[...] é muito 'tri" perguntar pra eles como era". Nesse encontro o grupo também ressaltou o quão "legal" era poder visitar e ver outro lugares "cheios" de história (DIÁRIO DE CAMPO, 21/09/2016).

\title{
b) Edição
}

Levou em torno de duas semanas o processo de edição das imagens coletadas. A proposta de que o vídeo tivesse em torno de 20 a 25 minutos de duração, foi deliberada pelo grupo. Devido ao tempo disponível, o processo "braçal" de edição (recorte, colagem, transições, etc.) foi realizado pelos pesquisadores, mas sempre norteado pelas demandas dos alunos ${ }^{4}$. Deste modo, foi dada agilidade ao processo de edição, já que o tempo para a realização da pesquisa deveria ser cumprido.

c) Produto

Após o término da edição, realizou-se um encontro (dia 05/10/2016) para dialogar sobre o documentário. O grupo acolheu bem o vídeo, demonstrando ter gostado do produto.

\begin{abstract}
Após assistir ao documentário o grupo aplaudiu e disse ter gostado muito do resultado, com falas do tipo: "Show", "Da ora", "Tri", etc.". Demonstraram satisfação com o resultado. Além dos elogios deram algumas sugestóes para colocar elou cortar algumas falas, assinalando um olhar crítico sobre o documentário (DIÁRIO DE CAMPO, 05/10/2016).
\end{abstract}

A partir das correções realizadas no documentário deu-se por encerrada a produção, ficando, assim, o filme pronto para a apresentação na Feira do Conhecimento.

O audiovisual inicia com falas que relacionam o período de infância, a juventude e a maturidade dos entrevistados perpassada pelas práticas de plantio e trabalho. As relações comerciais e as mudanças que ocorrem a partir do uso de máquinas na agricultura dão o tom da narrativa.

${ }^{4}$ Utilizamos o software Adobe Premiere

Reflexão e Ação [ISSN 1982-9949]. Santa Cruz do Sul, v. 28, n. 1, p. 254-272, jan./abr. 2020.

https://online.unisc.br/seer/index.php/reflex/index 
Ao longo do documentário se relembra o passado no meio rural até chegar ao presente, abordando a relevância que as máquinas têm para o mundo agrícola. Desse modo se exploram os processos de mudanças no meio produtivo e no próprio cotidiano.

d) Mostra

O vídeo foi exposto em novembro de 2016 na Feira do Conhecimento para a comunidade e também passou por avaliadores que a escola escolheu. Os avaliadores fizeram referências à importância de produzir um audiovisual sobre a agricultura em Paverama, principalmente devido à valorização do conhecimento dos agricultores. Além disso, teceram elogios sobre a participação dos alunos na produção e da própria apresentação na Feira.

A comunidade que visitou a Feira reconheceu muitos dos entrevistados, o que gerou comentários por parte dos alunos. No sábado, dia 22, a pesquisa foi premiada, como um dos melhores trabalhos expostos na feira.

\section{REFLEXÕES}

O tema "Agricultura: do manual ao automático", ao ser escolhido pelos alunos, respeitou sua curiosidade, pois convocou "[...] a imaginação, a intuição, as emoções, a capacidade de conjecturar, de comparar [...]" (FREIRE, 2015a, p.85) trazendo-a como elemento fundamental da pesquisa.

A saída a campo do dia nove de novembro demonstrou que, por curiosidade, foram exploradas falas, lugares e situações novas, pois surgiu interesse em conhecer uma casa "antiga" que havia na localidade (Fig. 1). Os alunos se encantaram com os objetos "antigos" e gostaram da explicação dada por um entrevistado

A partir da fala do agricultor entrevistado e da curiosidade dos alunos foi possível mostrar que a história pessoal e a afetividade de quem viveu e conviveu com lugares/objetos muda a maneira como se conta e enriquece o relato, trazendo à tona a saudade, o olhar delicado e sentimental sobre o físico, transcendendo apenas o usual, construindo memórias (DIÁRIO DE CAMPO, 10/09/2016).

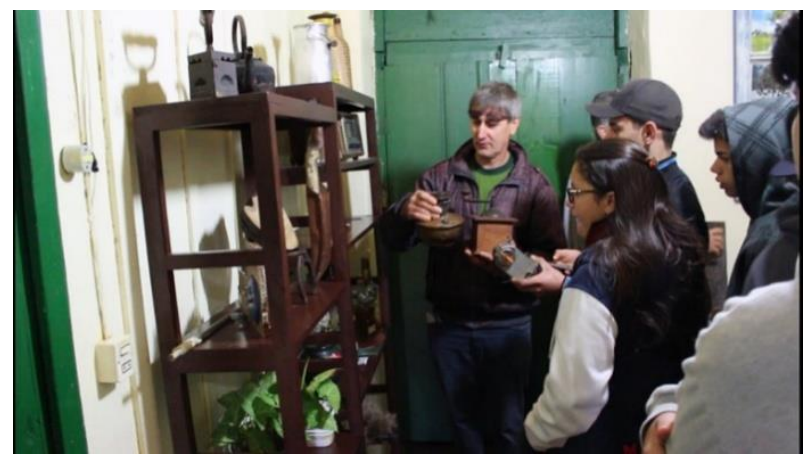

Fig. 1. Fonte: Dos autores.

Observou-se que a escolha dos entrevistados engajou os alunos, pois empoderaram-se quando assumiram a responsabilidade de encontrar pessoas dispostas a participar do projeto. Também os alunos retrataram as brincadeiras e momentos das entrevistas (Fig. 2), demonstrando uma apropriação das mídias e o aproveitamento do espaço de aprendizagem para expressão do lúdico. 


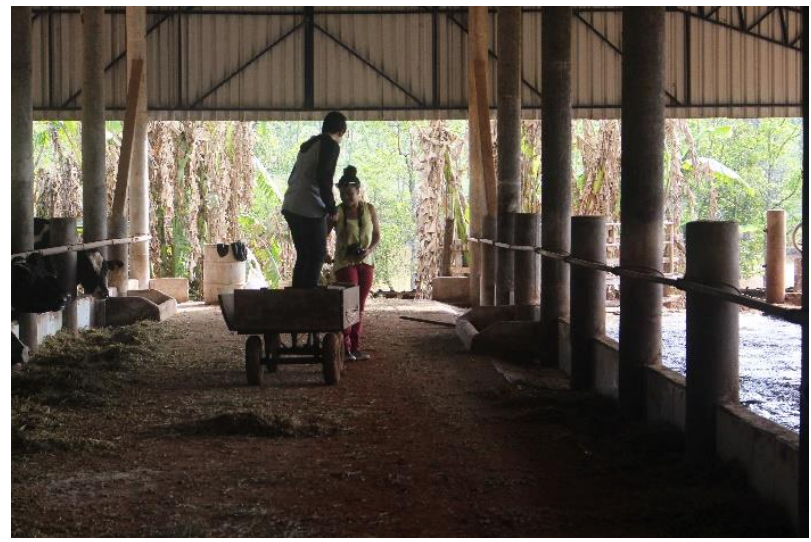

Fig. 2. Fonte: Dos autores.

Segundo Paulo Freire (2015a), ensinar exige respeito à autonomia e à singularidade do educando. Tendo em vista tal proposição, não se "forçou" o aluno a filmar, deixando ele a "seu tempo" para essa apropriação, o que demonstrou-se profícuo, pois, pouco a pouco, todos fotografaram, filmaram (Fig. 3), brincaram e entrevistaram, participando assim das diferentes etapas e funções da construção do vídeo. Podemos inferir que as singularidades apareceram, embora tenha prevalecido a importância do grupo.

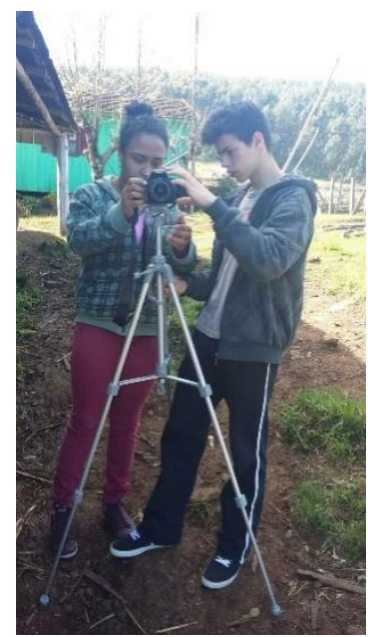

Fig. 3. Fonte: Dos autores.

Ao longo das gravações os alunos mostraram-se questionadores, exercitando o pensar, capital mais precioso para o indivíduo e para a sociedade, como coloca Morin (2000). Considera-se que a informação, cada vez mais presente em volume e importância na sociedade, pode ser a matéria-prima do conhecimento. Para isso, o participante precisa dominá-la e transformá-la em saber significante, o que aconteceu quando o ato de entrevistar gerou engajamento do grupo na produção e exercitou a escuta do outro (Fig. 4). 


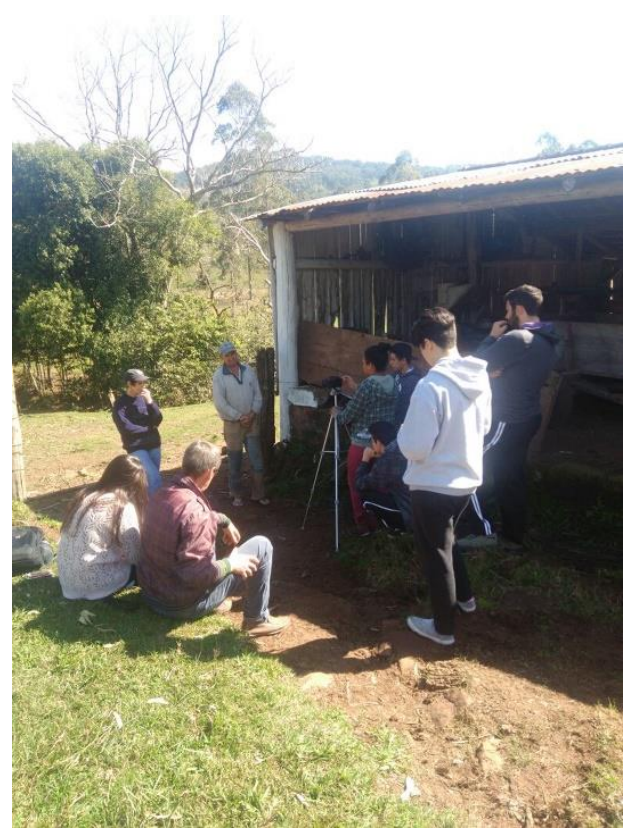

Fig. 4. Fonte: Dos autores.

A comunicação didática do conhecimento é meio, instrumento e código, através dos quais os alunos tem a possibilidade de reconstruir e reelaborar o saber (RANGEL; FREIRE, 2010). Foi dessa forma que a produção audiovisual possibilitou uma comunicação didática de alunos para com outros alunos, com professores e com a comunidade.

Morin (2005, p.25) chama atenção para a importância de observar inter-retro-ações entre o fenômeno e seu contexto, atentando-se para reciprocidade entre todo/partes, entendendo como uma "[...] modificação local repercute sobre o todo e como uma modificação do todo repercute sobre as partes". Esta inter-retro-ação verificou-se em dois momentos:

Na Feira do Conhecimento, muitos visitantes notaram e reconheceram vizinhos, parentes e amigos no documentário, o que gerou certa curiosidade e fez com que muitos assistissem ao vídeo. A prática de exposição do audiovisual gerou aproximação com a comunidade, desde a produção até a exposição do audiovisual (DIÁRIO DE CAMPO, 21/10/2016)

Também a inter-retro-ação se deu quando o grupo criou e armazenou falas, expressões, visões e vivências que enriquecem a pesquisa em História e em outras áreas.

Discutiu-se sobre as possibilidades de "armazenamento" de memória que realizamos a partir do documentário e buscou-se demonstrar aos alunos a importância de se "preservar e guardar" essas memórias para futuras pesquisas (DIÁRIO DE CAMPO, 14/09/2016). 
O processo de produção audiovisual evidenciou a prevalência de alguns princípios da educomunicação, dentre eles o diálogo. A dialogicidade contínua e permanente auxiliou no ensino, na aprendizagem e na pesquisa realizada pelos alunos, ao promover sua inclusão nos processos de tomada de decisão e construção do audiovisual, tornando-os ativos no processo educativo. Diferente do que Paulo Freire (2005) delimita como uma educação bancária, foi possível, através do diálogo, fazer com que os envolvidos na pesquisa retroalimentassem o processo de produção de conhecimento. Se pretendemos educar para a era planetária, para a educação mais humanizada, como propõe Morin (2000), o diálogo deve existir. A dialogicidade e a troca devem ser ampliadas, utilizadas para gerar desenvolvimento pessoal e coletivo.

Colocar os estudantes no centro do processo, não como alguém que recebe uma extensão informacional (simples receptor), mas sim como um participante ativo, dialógico e decisivo, possibilita novos olhares e possibilidades de transformação da educação (FREIRE, 2015b). Fica clara a importância do diálogo ao se observar que gerou relações mais próximas entre o mediador/pesquisador e o grupo, o que favoreceu o ambiente de aprendizagem, com o aluno e o professor no centro da tomada de decisão sobre as ações.

Através da produção participativa os envolvidos tornam-se construtores e não somente repetidores de informação. Atuaram em parceria e desenvolveram organização, o que gerou um processo de cidadania, com exercício da autonomia e da visão crítica, decorrentes do questionamento e da participação, como expõe Freire (2015a). Isso foi exercitado pelos alunos. Sabemos que é necessário mais do que essa produção para tornar alguém autônomo, mas evidenciou-se que essa prática afetou o grupo. Demo (2009) escreve que para aprender bem o aluno tem de estar no centro, ativo, o que aconteceu quando foram envolvidos no processo de decisão e expostos ao papel de alunopesquisador.

A participação se tornou meio e instrumento para que os alunos, em conjunto, reconstruíssem e reelaborassem o saber dos entrevistados e o seu próprio, de acordo com suas práticas de vida e com o contexto no qual se inserem. Apropriar-se do conhecimento e transformá-lo, ressignificando-o em processos comunicativos abertos ao diálogo através da participação, coloca-se como atitude/ação profícua e fértil aos processos de ensino e de aprendizagem (RANGEL; FREIRE, 2010; FREIRE, 2015b).

Quando tanto no campo da educação como especificamente no da educomunicação evidenciase a relevância da transversalidade, podemos pensá-la a partir de Morin (2003) que a coloca como ponto significante para unir os progressos feitos pela ciência até então. Esses progressos encontramse compartimentados, desunidos e separados em "gavetas", necessitando uma aproximação e "ligação de pontos", para alcançar aprendizagens complexas.

O trabalho buscou a transversalidade quando abordou aspectos sociais, políticos, econômicos, culturais e tecnológicos. Pode-se também vincular a história com a geografia quando se pensa o espaço como determinante para alguns cultivos e atividades, com a matemática e a economia, quando se abordou as políticas de crédito do governo e o aumento da produção, com as artes ao se deparar com fotografias, pinturas e festas que aconteciam ou ainda acontecem, assim como as expressões religiosas.

Reflexão e Ação [ISSN 1982-9949]. Santa Cruz do Sul, v. 28, n. 1, p. 254-272, jan./abr. 2020. 
O diálogo de saberes se evidenciou com a troca que ocorreu ora entre áreas do conhecimento, ora entre grupo-mediador-entrevistado. As conversas entre os entrevistados e o grupo gerou o encontro de subjetividades, materialidades e espiritualidades (DEMO, 2009), principalmente quando recorreram à memória para contar sobre seu lugar no mundo e suas vivências (CALDAS, 1999; LE GOFF, 2003). A partir dos saberes dos envolvidos na pesquisa (entrevistados, grupo e pesquisadores), transitou-se entre diferentes saberes e visões, desencadeando a construção de conhecimentos, ou, como escreve Júnior (2009) teceram-se histórias.

O historiador não trabalha numa linha de montagem, onde tudo vem no seu devido lugar e tempo (JÚNIOR, 2009). Ele precisa juntar pedaços, retalhos e peças para "remontar" a partir do que possui, a própria História. A História é complexa, plural, relativa. Lidar com o tempo exige destreza, cuidado e aventura. Encontrar o que está implícito e, por vezes, "camuflado", sabendo que, o tempo mói os grãos e o historiador os cozinha. O aluno, ao pesquisar com profundidade e munido do que é preciso para fazer História, pode adentrar a "cozinha" e temperar através dos dados, das falas e de sua visão do assunto.

Valorizar o conhecimento popular é outro princípio da educomunicação que permeou o documentário. É também um elemento extremamente fértil para o terreno da história, que assim como acontece com os saberes tradicionais, têm muito a contribuir. A valorização dos saberes dos agricultores (comunidade), professores e alunos, exercitada na produção do documentário mostrou-se um elemento fundamental no processo de comunicação que se dá no fazer educativo, que fez dos estudantes co-participantes, intencionados a comunicarem-se consigo, entre si e com o mundo, como sujeitos ativos do seu mundo e da pesquisa que o adentrou (FREIRE, 2015b).

Já se reconhece que a mídia e as novas tecnologias estão provocando uma "alfabetização múltipla", deslocando algumas vezes o "lugar" do conhecimento e criando um choque entre a cultura popular e a cultura midiática. No entanto, no uso de mídia em um processo de educomunicação podemos gerar práticas que formam sujeitos conscientes dos saberes e suas complementariedades, fazendo interagir a partir da escola, o popular com o saber científico (BACCEGA, 2014; HUERGO, 2014).

A valorização da tradição e do popular é um elemento do campo da História, especificamente da História Nova (LE GOFF, 1998), que abre espaços para o jogo de construção cotidiana, onde se forma o que Júnior (2009) denomina colcha de retalhos de saberes que constituem o saber histórico e historiográfico.

A democratização da comunicação, outro princípio educomunicativo, evidenciou-se porque os alunos puderam "falar" através do documentário, assim como os agricultores. A possibilidade de expressão comunicativa pode fazer do ensino e da pesquisa algo mais significativo, além de compreender de onde surgem os "grãos moídos" e os já cozidos (FREIRE, 2015b; JÚNIOR, 2009).

Conversamos sobre como é produzida a informação que nos chega, via TV principalmente [...] se expôs e fez-se uso das práticas da produção audiovisual do grupo para demonstrar que, se quisermos editar podemos dar outros significados às falas e comunicar outras intenções [...] (DIÁRIO DE CAMPO, 05/10/2016). 
Ao se explorarem formas de mediação tecnológica em espaços educativos, percebeu-se que podemos usar o aparato que tivermos à disposição para criar, pesquisar e acessar informações, desmitificando, democratizando e colocando a tecnologia à serviço da sociedade, da pesquisa e do ensino. Isso requer uma gestão eficaz da comunicação e, como escreve Soares (2011), que além de produzir, se dê visibilidade à produção. Quando a gestão é eficaz, é possível fazer circular o conhecimento e "atingir" mais pessoas, aproveitando as conexões e as redes criadas pela internet, por aplicativos de celular e em programas de computador.

Mas não nos basta apenas transitar pela informação, diz Demo (2007). É preciso que ela se transforme em um elemento de um processo de comunicação, de intercompreensão. Para Freire (2015b), a educação é comunicação e diálogo "[...] na medida em que não é a transferência de saber, mas um encontro de sujeitos interlocutores que buscam a significação dos significados" (p. 91). Na construção do documentário o processo educativo se deu por apropriação. A educação transformou-se em conhecimento próprio, já que as práticas suscitaram aprendizagens.

O respeito à individualidade e à diversidade humana, assim como a não discriminação preconceituosa, tendo como norte a luta pela igualdade de oportunidades e manifestações plurais, é outro princípio que foi levado em conta na produção audiovisual.

Os percursos dos participantes mostram que, desde a mais tenra idade, as pessoas já vivenciam experiências e acontecimentos em suas vidas, responsáveis por sinalizar os recursos que poderão ser utilizados na corrida por seus objetivos. Tais experiências e acontecimentos vão ajudando a delinear a práxis profissional que vão construindo, e transformando, a fim de se aperfeiçoarem naquilo que fazem.

\footnotetext{
Dialogou-se muito sobre como são diferentes os próprios agricultores e suas práticas de vida. Abordou-se a questão do estereótipo que muitas vezes caracteriza o agricultor (como alguém sem conhecimento) e demonstrou-se que a sabedoria e o conhecimento que eles tem são adequados as suas práticas e que o grupo é heterogêneo, tanto no modo de trabalhar quanto no modo de viver [...] (DIÁRIO DE CAMPO, 14/09/2016).
}

Esta observação de campo nos leva a Morin (2000, p. 50), quando escreve que "[...] Compreender o humano é compreender sua diversidade na unidade, sua unidade na diversidade". Respeitar as individualidades enquanto tal é de suma importância para a aprendizagem. A produção audiovisual alinhou-se a esta perspectiva quando aproximou-se dos agricultores. Não é raro ver representações nas mídias comerciais do agricultor como um sujeito inculto e que pouco "sabe" das coisas. Discurso que, por vezes, os próprios agricultores interiorizam e repetem.

Foi interessante notar a surpresa dos alunos ao verem que muitos agricultores estudam (ou estudaram), têm acesso à internet e leem revistas para melhorar a produção. Um entrevistado explicou como, no plantio direto, se abrem sulcos na terra, o que se revelou um momento de troca de saberes. Entende-se, assim, que produções que mostrem o cotidiano e o conhecimento de determinados grupos sociais, como ocorreu na construção do documentário, podem desconstruir estereótipos, enfrentando a complexidade, entendida por Morin (2000) como a união entre a multiplicidade e a unidade, que possibilita conhecer, desmistificar, produzir e cooperar com o outro. 
Durante o processo de intervenção, além de atentos aos princípios da educomunicação, buscamos também fazer o que Soares (2011) sugere: perpassar o máximo de subáreas da educomunicação. Verificou-se que a produção possibilitou trabalhar a subárea de expressão comunicativa. Para Soares (2011), através do uso dos recursos, da informação e das artes é possível gerar conhecimento, aumentando o potencial de emancipação e a criação dentro da comunidade educativa. Para isso, deve-se ter acesso aos conteúdos e condições de produzir seus próprios conteúdos de expressão.

Entre as habilidades desenvolvidas no processo de produção do documentário está a de construção de narrativas, que é pouco exercitada pela escola. Com a produção audiovisual alunos e agricultores puderam expressar-se a partir de um suporte criativo. O protagonismo se evidenciou no processo de construção de narrativa, quando o Aluno B diz: "[...] não dá para colocar essa parte. Não vai ligar com a anterior. Vamos colocar apenas eles falando da infância" (DIÁRIO DE CAMPO, 30/09/2016).

Ao passarem de receptores a produtores de informação os alunos romperam com limites, demonstrando que muito se tem a ganhar com a produção de conteúdos, especialmente quando for de forma colaborativa. Para isso, precisa-se ir além do simples consumo midiático.

A partir da produção do documentário foi possível explorar um pouco o âmbito da educação para a comunicação, pois, ao se entender como se dá a produção e edição de um vídeo e através do diálogo mediador-grupo, problematizou-se a produção de conteúdos audiovisuais (cinema, TV, etc.) em uma leitura mais "crítica" da mídia.

Ler a partir da mídia de forma crítica é um desafio que vem sendo tratado, na América Latina, principalmente, a partir da década de 1970. Com as novas tecnologias e os deslocamentos que causaram, alteram-se as fronteiras entre razão e imaginação, saber e informação, saber científico e senso comum (MARTÍN-BARBERO, 2011), criando-se assim um cenário desordenado onde há muita informação e nem sempre muito conhecimento, requisitando uma educação para a leitura da informação midiática.

A crítica da mídia está intrinsecamente relacionada ao que Soares (2011) designa como mediação tecnológica nos espaços educativos, que se dá quando coloca-se a tecnologia a serviço do grupo, explicando seus usos e democratizando seu acesso.

O sistema de educação formal como um todo parece resistir em reconhecer que cada vez mais se encontra distante das "novas gerações" e, muitas vezes, acaba até "barrando" o uso dessas tecnologias. O modo como lemos está mudando, telas invadem nosso dia-a-dia, afetam sensibilidades e subjetividades, enquanto a escola parece mudar em um ritmo lento (DEMO; 2007; FLUSSER, 2007). Estas diferenças de temporalidades geram atritos e resistências.

Demo (2009) refere que há um grande distanciamento entre como a escola trabalha e como o aluno vive. A mediação tecnológica pode nos auxiliar nesta reaproximação entre espaço escolar e cotidiano do aluno, levando-se em conta como ele se relaciona com o mundo, percebendo as tecnologias para além da lógica mercantil e consumista. Necessitamos ver e fazer uso de suas 
potencialidades para a cidadania, possibilitando direito à comunicação, para se atuar na mudança da realidade, na criação de sujeitos críticos e de agentes ativos de seu tempo (FREIRE, 2015a).

Quanto à subárea da pedagogia da comunicação, houve uma abertura quando um professor aceitou participar do processo, mesmo fora do horário de trabalho. Por mais que apenas um professor tenha participado e não tenha comparecido em todos os encontros, ocorreu a aproximação, o que foi reconhecido pelos alunos como algo incomum.

Demo (2009) refere que o problema não é usar tecnologias nos espaços escolares, porque essas são utilizadas, porém geralmente não se aprimora a aula e nem se torna discente ou docente autores, mas sim espectadores e/ou copiadores. Para o autor o espaço escolar, vive uma "[...] contradição lancinante, porque não é local de aprendizagem consistente, muito menos de uso tecnológico minimamente adequado. [...]" (2009, p.88).

Levaremos tempo para entender como cada tecnologia funciona e quais os melhores usos, por isso, o melhor caminho é realmente ampliar os usos e aprimorá-los, aposta Flusser (2007). Precisamos experimentar mais, arriscar, criar, vivenciar novos usos, experienciando de maneira crítica e consciente.

A falta de formação em educomunicação faz com que a gestão da comunicação em espaços escolares se encontre pouco desenvolvida. No entanto, este artigo deixa como contribuição a demonstração de que é possível, por meio de processos participativos, produzir conhecimento com os alunos e enfrentar esse desafio.

Para isso é preciso criar ecossistemas comunicativos dentro do espaço escolar. Para Soares (2011) o ecossistema comunicativo refere-se a relações construídas coletivamente em dado espaço, tendo-se como estratégia o favorecimento do diálogo social, levando em conta as potencialidades dos diferentes meios de comunicação.

O uso desse termo é metafórico, remetendo ao conceito no meio geofísico-biológico. Segundo Soares (2011) ao transferi-lo para o meio social, nota-se que há sistemas "áridos" e fechados de interconexões, ao passo que podem existir sistemas ricos e intensos de expressão e conectividade. A escola carece de ecossistemas comunicativos.

As tecnologias de comunicação demonstraram seu potencial. Se pretendemos uma educação conectada e significativa precisamos experienciar, criar, lambuzar-se de saber.

\section{REFERÊNCIAS}

Reflexão e Ação [ISSN 1982-9949]. Santa Cruz do Sul, v. 28, n. 1, p. 254-272, jan./abr. 2020.

https://online.unisc.br/seer/index.php/reflex/index 
AGROSINO, Michael. Etnografia e observação participante.Porto Alegre: Artmed, 2009.

2. APARICI, Roberto. Introdução: a educomunicação para além do 2.0. In: (Org.). Educomunicação: para além do 2.0. 1. ed. São Paulo: Paulinas, 2014. p. 29 - 39.

3. BACCEGA, Maria Aparecida. Comunicação e consumo: educação e cidadania. In: ROCHA, Rose de Melo; OROFINO, Maria Isabel Rodrigues (Orgs.). Comunicação, consumo e ação reflexiva. Porto Alegre: Sulina, 2014. p. 189 - 204.

4. BRASIL. Programa Nacional de Educomunicação Socioambiental: Série documentos técnicos 2 . Órgão Gestor da Política Nacional de Educação Ambiental, Brasília, DF, 2005. Disponível em <http://www.mma.gov.br/estruturas/educamb/_arquivos/dt_02.pdf>. Acesso em 10 nov. 2016.

5. BRAUDEL, Fernand. História e Ciências Sociais. A longa duração. In: (Org.). Escritos sobre a História. São Paulo: Perspectiva, 1992. p. 41 - 78. CALDAS, Alberto Lins. Oralidade, texto e história: para ler a história oral. Edições Loyola. São Paulo, 1999.

7. DEMO, Pedro. Educação hoje: "novas" tecnologias, pressões e oportunidades. São Paulo: Atlas, 2009. .O Porvir: desafio das linguagens do século XXI. Curitiba: Ibpex, 2007.

9. ECKERT, Cornelia; ROCHA, Ana Luiza Carvalho. Etnografia: saberes e práticas. In: PINTO, Regina Jardim Pinto; GUAZZELLI, César Augusto Barcellos (Orgs.). Ciências Humanas: pesquisa e método. Porto Alegre: Editora da Universidade, 2008. 23 p.

FLUSSER, Vilém. O mundo codificado: por uma filosofia do design e da comunicação. São Paulo: Cosac Naify, 2007.

11. FREIRE, Paulo. Extensão ou comunicação. 17. ed. São Paulo: Paz e Terra, 2015b.

12. Pedagogia da autonomia: saberes necessários à prática educativa. 43. ed. São Paulo: Paz e Terra, 2015a. . Pedagogia do Oprimido. 42. ed. Rio de Janeiro: Paz e Terra, 2005. 

(Orgs.). Pesquisa qualitativa com texto, imagem e som - um manual prático. Petrópolis: Vozes, 2002. p. $64-73$. Janeiro: Bertrand Brasil, 2003.

23

24 UNESCO, 2000.

HUERGO, Jorge A. Um guia de comunicação/educação, pelas transversais da cultura e da política. In: APARICI, Roberto (Org.). Educomunicação: para além do 2.0. São Paulo: Paulinas, 2014. p. $83-91$.

17. JÚNIOR, Durval Muniz de Albuquerque. O tecelão dos tempos: o historiador como artesão das temporalidades.In: Negro, Antônio L.; SOUZA, Evergton Sales; BELLINI, Lígia (Orgs.). Tecendo histórias: espaço, política e identidade. Salvador: EDUFBA, 2009. p.13 - 26.

LARROSA, Jorge Bondía. Notas sobre a experiência e o saber da experiência. Revista Brasileira de Educação. Jan/Fev/Mar/Abr, v. n. 19, 2002. p. 20 - 29.

LE GOFF, Jacques. A História Nova. IN: ; CHARTIER, Roger; REVEL, Jacques (Orgs.).A História Nova. 4. ed. São Paulo: Martins Fontes, 1998. p. 17 - 44.

LE GOFF, Jacques. História e Memória. 5 ed. Campinas, SP: Editora da Unicamp, 2003.

MARTÍN-BARBERO, Jesus. Desafios Culturais: Da Comunicação à Educomunicação. In: CITELLI, Adilson Odair; COSTA, Maria Cristina Castilho (Orgs.). Educomunicação: construindo uma nova área do conhecimento. São Paulo: Paulinas, 2011. p. 121-134.

MORIN, Edgar. A cabeça bem-feita: repensar a reforma, reformar o pensamento. 8. ed. Rio de . Introdução ao pensamento complexo.5. ed. Porto Alegre: Ed. Sulina, 2005.

Sociedade Midiatizada. Rio de Janeiro: Mauad, 2006. p. 193 - 220. 
27. SEPAC - Serviço à Pastoral da Comunicação. Vídeo, da emoção à razão. São Paulo: Paulinas, 2007.

SOARES, Ismar de Oliveira. Caminhos da educomunicação: utopias, confrontações, reconhecimentos. In: APARICI, Roberto (Org.). Educomunicação: para além do 2.0. São Paulo: Paulinas, 2014. p. 8 - 26. Educomunicação - o conceito, o profissional, a aplicação: contribuições para a reforma do ensino médio. São Paulo: Paulinas, 2011.

VERGARA, Sylvia C. Projetos e relatórios de pesquisa em administração. São Paulo: Atlas, 2005.

\section{Rodrigo Müller Marques}

Graduado em História e Mestre no Programa de Pós-Graduação em Ambiente e Desenvolvimento na Universidade do Vale do Taquari - Univates.

\section{Jane Márcia Mazzarino}

Possui doutorado em Ciências da Comunicação pela Universidade do Vale do Rio dos Sinos (2005), mestrado em Ciências da Comunicação pela Universidade do Vale do Rio dos Sinos (2001) e graduação em Comunicação Social com Habilitação em Jornalismo pela Universidade do Vale do Rio dos Sinos (1991). Atualmente é professora titular do Centro Universitário Univates. Atua no Programa de Pós-Graduação Ambiente e Desenvolvimento (mestrado e doutorado), e nos cursos de graduação em Comunicação Social. Coordena o projeto de pesquisa-extensão Comunicação, Educação Ambiental e Intervenções (Ceami CNPq).

\section{Como citar este documento}

MARQUES, Rodrigo Müller; MAZZARINO, Jane Márcia. O que pode a intervenção educomunicativa audiovisual? Relatos de uma experiênciação. Reflexão e Ação, Santa Cruz do Sul, v. 28, n. 1, jan. 2020. ISSN 1982-9949. Disponível em:

<https://online.unisc.br/seer/index.php/reflex/article/view/11196>. Acesso em: doi:https://doi.org/10.17058/rea.v28i1.11196. 